\title{
Improving Students' Translation Mastery by Hypnoteaching Implementation
}

\author{
Juwita Boneka Sinaga \\ English Education Department \\ University of Riau Kepulauan \\ juwitaboneka@gmail.com
}

\begin{abstract}
There is a need to know why students feel so nervous and lack of confidence when speaking. There may be a relationship between their metacognitive strategy and their self-efficacy in speaking skill. This research aimed at improving students' translation mastery by hypnoteaching implementation. Hypnoteaching stands for two wordshypnosis and teaching. Majid defines hypnosis as a condition like a sleep called trance due to the reduction of brain wave from beta to alpha or theta. In this condition, the client's conscious mind is opened and the hypnotist can give suggestions directly to the subconscious mind. This research was a quantitative research classified into a true experimental design. In this research, the instrument that used was multiple choice consist of 10 items. The researcher used t-test formula to find out whether there was a significant difference between the both classes after being treated. Based on the findings on the discussion, the researcher concluded that the implementation of Hypnoteaching method effectively improves the second year students' translation ability at SMA Negeri 6 Padangsidimpuan, Bone. It could be proven by looking at the comparison between the Ttest value and T-table value. The T-test value is 5.957 and with $1 \%$ of significance level and 38 degree of freedom, T-table value is 2.712 because the T-test value is higher than $T$-table, the null hypothesis $\left(H_{0}\right)$ is rejected and the alternative hypothesis $\left(H_{a}\right)$ is accepted. That significant improvement could be observed in the students' motivation while the learning process runs.
\end{abstract}

Keywords: translation mastery, hypnoteaching

\section{INTRODUCTION}

Translation is the process of transferring meaning such as; transferring meaning English to Indonesian or Indonesian to English. So, to know the information, message, or knowledge in English text, the first, students must translate by using dictionary into Indonesian. That is why the students who learn English as the foreign language also needs translation, so when they graduate from their school or university they will be able to use 
their skills but so far the students cannot master translation well. There are still many students can not used English in a good way. It can be seen from this dialogue below:

Teacher : Why were you absent yesterday?

Student : Sorry Sir, my body was not delicious yesterday.

Teacher : Don't be afraid, I won't eat you

From the example above, has shown that the students could not use English based on the context. In increasing the students translation mastery, there are so many kinds of strategies can be used by the teacher such as: demonstration method, discussion method, group work method, experiment method and hypnoteaching skill.

The newest method is developed from Hypnosis integrated in teaching process called Hypnoteaching. It is still heard strange for the most Indonesian Teachers, but some researches prove that the method is proven effectively in improving the students skills. So, the writer tries to apply this method in learning-teaching process especially in translating comprehension at SMA Negeri 6 Padangsidimpuan, because the school is located in crowded town. Besides that, most teachers there still lack of knowledge about the Hypnosis or Hypnoteaching. The two reasons become the main consideration by the researcher to implement the method at the school. In the implementation, a Teacher will spend 10 to 15 minutes at the beginning of each meeting to hypnotize students before learning-teaching process is begun. The teacher will bring students' mind wave from beta state to alpha or theta called trance. According to Gunawan (2007), alpha state is a condition where the brain waves become extreme low, making it easier to open up the subconscious mind. In this condition, the mind will be very easily and quickly receive information through a suggestion. At the moment, the teacher can give positive suggestions verbally about how to be able in translating.

Based on the explanation above the writer wanted to do a research about the

\section{"IMPROVING STUDENTS TRANSLATION MASTERY BY HYPNOTEACHING IMPLEMENTATION AT THE SECOND YEAR OF SMA NEGERI 6 PADANGSIDIMPUAN."}

The hypnoteaching itself is integrated from five teaching-learning methods i.e. quantum learning, accelerate learning, power teaching, neuro linguistic programming, and 
hypnosis. The hypnoteaching process starts from hypnotize the students (bring the students to their trance) and than give them positive suggestions.

In Hypnosis or Hypnoteaching, there are some special terms used in its process like as follows:

\section{1) Hypnotist}

A man who hypnotizes or gives suggestions to the client through an induction. The hypnotist is the subject in the hypnotizing process.

\section{2) Hypnotizing}

Hypnotizing is the process of bringing a client's mind from his conscious mind to sub-conscious mind by some suggestion through an induction.

\section{3) Client}

A client is an object in hypnosis process by an hypnotist. In Hypnoteaching, the clients refers to the students .

\section{4) Induction}

An induction is a method to make the client in trance condition. The hypnotist will focus the students' mind by some techniques to bring them in their trance.

\section{5) Suggestion}

A suggestion is sentences uttered by using a particular technique and situation. The sentences can influence the subject based on the purpose of the suggestion.

\section{Hypnoteaching: Giving}

positive suggestion to improve listening ability
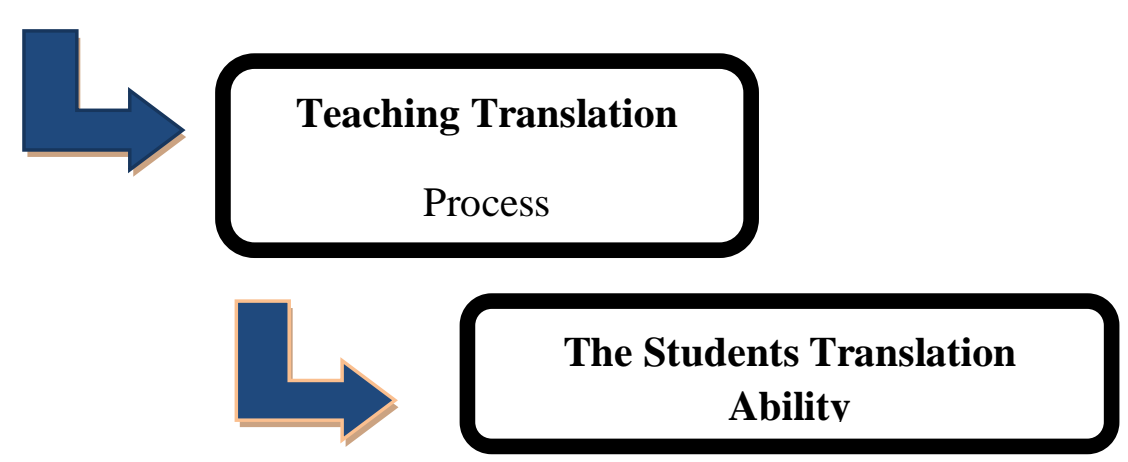


\section{METHODOLOGY}

This research is a quantitative research classified into a true experimental design. The design used pre-test and post-test design is applied to the both classes: experimental class and controlled class. The experimental class will be applied hypnoteaching method, whereas the another class will not. The population of this research was the second year students of SMA Negeri 6 Padangsidimpuan. Because this research is a population research, the data source will be taken from the population. The population is divided into two classes (2 IPA dan 2 IPS) with 20 students for each class, so the number of students as the data source is 40 students. Consisting of two classes, the researcher decided Class 2 IPS as the experimental class and Class 2 IPA as the controlled class. The students of both classes are the subject and the data source of this research. In this research, the instrument that used is multiple choice consist of 10 items.

\section{RESULTS}

\section{The Classification of Students' Pre-test and Post-test Scores in Experimental Class}

Table 1. The rate percentage of experimental class' score in pre-test

\begin{tabular}{lllcc}
\hline No. & Classification & Score & Frequency & $\begin{array}{c}\text { Percentage } \\
(\boldsymbol{\%})\end{array}$ \\
\hline $\mathbf{1 .}$ & Excellent & $9.6-10$ & 0 & 0 \\
\hline $\mathbf{2 .}$ & Very good & $8.6-9.5$ & 0 & 0 \\
\hline $\mathbf{3 .}$ & Good & $7.6-8.5$ & 0 & 0 \\
\hline $\mathbf{4 .}$ & Fairly good & $6.6-7.5$ & 0 & 0 \\
\hline $\mathbf{5 .}$ & Fairly & $5.6-6.5$ & 0 & 0 \\
\hline $\mathbf{6 .}$ & Poor & $3.6-5.5$ & 5 & 25 \\
\hline $\mathbf{7 .}$ & Very poor & $0-3.5$ & 15 & 75 \\
\hline & Total & & $\mathbf{2 0}$ & $\mathbf{1 0 0 \%}$ \\
\hline
\end{tabular}

Table 1 above shows the rate percentage and frequency of the students of experimental class in pre-test, no one of the students got excellent, very good, good, fairly good and fairly. There were 5 students (25\%) got poor score and the other 15 students $(75 \%)$ got very poor. 
Table 2. The rate percentage of experimental class' score in post-test

\begin{tabular}{llccc}
\hline No. & Classification & Score & Frequency & $\begin{array}{c}\text { Percentage } \\
(\mathbf{\%})\end{array}$ \\
\hline 1. & Excellent & $9.6-10$ & 0 & 0 \\
\hline 2. & Very good & $8.6-9.5$ & 2 & 10 \\
\hline 3. & Good & $7.6-8.5$ & 3 & 15 \\
\hline $\mathbf{4 .}$ & Fairly good & $6.6-7.5$ & 8 & 40 \\
\hline $\mathbf{5 .}$ & Fairly & $5.6-6.5$ & 7 & 35 \\
\hline $\mathbf{6 .}$ & Poor & $3.6-5.5$ & 0 & 0 \\
\hline $\mathbf{7 .}$ & Very poor & $0-3.5$ & 0 & 0 \\
\hline & Total & & $\mathbf{2 0}$ & $\mathbf{1 0 0 \%}$ \\
\hline
\end{tabular}

Table 2 above shows that in post-test, 2 students (10\%) got very good, 3 students (15\%) got good, 8 students (40\%) got fairly good, and 7 students (35\%) got fairly. No students got poor and very poor.

Based on the result above, it can be concluded that the rate percentage in the posttest was higher than the percentage in pre-test with a significant difference.

\section{The Classification of Students' Pre-test and Post-test Scores in Controlled Class}

Table 3. The rate percentage of controlled class' score in pre-test

\begin{tabular}{llccc}
\hline No. & Classification & Score & Frequency & $\begin{array}{c}\text { Percentage } \\
(\boldsymbol{\%})\end{array}$ \\
\hline $\mathbf{1 .}$ & Excellent & $9.6-10$ & 0 & 0 \\
\hline $\mathbf{2 .}$ & Very good & $8.6-9.5$ & 0 & 0 \\
\hline $\mathbf{3 .}$ & Good & $7.6-8.5$ & 0 & 0 \\
\hline $\mathbf{4 .}$ & Fairly good & $6.6-7.5$ & 0 & 0 \\
\hline $\mathbf{5 .}$ & Fairly & $5.6-6.5$ & 0 & 0 \\
\hline $\mathbf{6 .}$ & Poor & $3.6-5.5$ & 4 & 20 \\
\hline $\mathbf{7 .}$ & Very poor & $0-3.5$ & 16 & 80 \\
\hline & Total & & $\mathbf{2 0}$ & $\mathbf{1 0 0 \%}$ \\
\hline
\end{tabular}

Table 3 above shows the rate percentage and frequency of the students' score in controlled class in pre-test, no one of the students got excellent, very good, good, fairly good, and fairly. There were 4 students (20\%) got poor and 16 students (80\%) got very poor. 
Table 4. The rate percentage of controlled class' score in post-test

\begin{tabular}{llccc}
\hline No. & Classification & Score & Frequency & $\begin{array}{c}\text { Percentage } \\
(\boldsymbol{\%})\end{array}$ \\
\hline 1. & Excellent & $9.6-10$ & 0 & 0 \\
\hline 2. & Very good & $8.6-9.5$ & 0 & 0 \\
\hline $\mathbf{3 .}$ & Good & $7.6-8.5$ & 0 & 0 \\
\hline $\mathbf{4 .}$ & Fairly good & $6.6-7.5$ & 1 & 5 \\
\hline $\mathbf{5 .}$ & Fairly & $5.6-6.5$ & 6 & 30 \\
\hline $\mathbf{6 .}$ & Poor & $3.6-5.5$ & 12 & 60 \\
\hline $\mathbf{7 .}$ & Very poor & $0-3.5$ & 1 & 5 \\
\hline & Total & & $\mathbf{2 0}$ & $\mathbf{1 0 0 \%}$ \\
\hline
\end{tabular}

Table 4 above shows that in post-test, there were no one of the students got excellent, very good, and good. There were 1 student (5\%) got fairly good, 6 students (30\%) got fairly, 12 students (60\%) god poor, and 1 student (5\%) got very poor.

Based on the result above, it can be concluded that the rate percentage in the posttest was greater than the rate percentage in pre-test but not too significant.

3. The Mean Score and Standard Deviation of Experimental Class and Controlled Class

After calculating the result of the students score, the mean score standard deviation of both classes are presented in the following table:

Table 5. The mean score and standard deviation of experimental class and controlled class in pre-test and post-test

\begin{tabular}{lcccc}
\hline \multirow{2}{*}{ Class } & \multicolumn{2}{c}{ Mean Score } & \multicolumn{2}{c}{ Standard Deviation } \\
\cline { 2 - 5 } & Pre-test & Post-test & Pre-test & Post-test \\
\hline Experiment & 2.95 & 7.00 & 1.12 & 0.95 \\
\hline Controlled & 2.75 & 5.00 & 1.09 & 1.00 \\
\hline
\end{tabular}

The significant score between experimental and controlled class can be known by using t-test. The result of t-test can be seen in table 6 as follows: 


\section{Table 6. Distribution the value of t-test and t-table}

\begin{tabular}{cc}
\hline T-Test Value & T-Table Value \\
\hline 5.957 & 2.712 \\
\hline
\end{tabular}

\section{DISCUSSION}

Based on the findings, the researcher finds that in the rate percentage of students' score no students of both experimental class and controlled class got fairly and above in the pre-test. All the students were just able to get poor and very poor. There were $25 \%$ of the students got poor and $75 \%$ got very poor in the pre-test of experimental class, whereas in the pre-test controlled class, $20 \%$ of the students got poor and other $80 \%$ got very poor. It shows that the rate percentage of both experiment and controlled class were very low and the the students' translation ability of the both class were almost same. In the rate percentage of the both class in the post-test, generally, the researcher concludes that there was a progress for both experiment and controlled class. The result shows that there were $10 \%$ of the students in experimental class got very good, $15 \%$ got good, $40 \%$ got fairly good, and the other $35 \%$ got fairly. In the controlled class, $5 \%$ of the students got fairly good, 30\% got fairly, $60 \%$ got poor, and other 5\% got very poor. Although there was a difference between experimental and controlled class' pre-test and post-test result, the result of the experimental class was higher than the controlled class. It can be proven by looking at the result that there was no student of experimental class got poor and very poor and there was no student of controlled class got good and above. The result of the score calculation finds the mean score of both classes to measure the average of the students' translation ability. The mean score of experimental class in the pre-test is 2.95 and 7.00 in the post-test. It shows the students' translation ability progress which increase significantly. Whereas, the mean score of controlled class in pre-test is 2.75 and 5.00 in the post-test. The result informs us that there was a progress of the students' translation ability but not as significant as the experiment class. The score ranges between the students of both classes are almost same in the pre-test. It proves that before the researcher gave treatments to the experimental class, there was no significant difference between the both class in translation ability and the data spread of experimental class in pretest and post-test was equal, and the controlled class was, too.

In deciding the hypothesis, the researcher used t-test formula to find out whether there was a significant difference between the both classes after being treated. After 
calculating the data by using the formula, the researcher finds that the t-test value is 5.957, whereas the t-table value is 2.712 with $1 \%$ of significance level and 38 of the degree of freedom. It means that the t-test value is higher than t-table value. So, based on the data, the null hypothesis $\left(\mathrm{H}_{0}\right)$ is rejected and the alternative hypothesis $\left(\mathrm{H}_{\mathrm{a}}\right)$ is accepted.

Based on the findings on the discussion, the researcher concludes that the implementation of Hypnoteaching method effectively improves the second year students' translation ability at SMA Negeri 6 Padangsidimpuan, Bone. It can be proven by looking at the comparison between the T-test value and T-table value. The T-test value is 5.957 and with $1 \%$ of significance level and 38 degree of freedom, T-table value is 2.712. Because the T-test value is higher than T-table, the null hypothesis $\left(\mathrm{H}_{0}\right)$ is rejected and the alternative hypothesis $\left(\mathrm{H}_{\mathrm{a}}\right)$ is accepted. That significant improvement could be observed in the students' motivation while the learning process runs. The students were very enthusiastic and spirited in involving themselves actively in learning process. Besides that, the students also were able to apply all translation techniques in learning translation based on the suggestion given to them in their trance. These reasons become the main key of the success of the method in improving the students' translation ability.

\section{REFERENCES}

Gunawan, Adi W. (2007). Hypnoteraphy: The art of subconscious restructuring. Jakarta: PT Gramedia Pustaka Utama. 